\title{
Religion and the Prizing of Peace
}

Finding the balance between holding on too tightly and holding on too loosely is a challenge in politics as well as psychology. As we have seen, most people have held their "selves" together in human coalitions by appealing to the gods of their in-group. This can provide motivation for self-transformation as well as for altruistic behavior even toward out-group members. However, under stressful conditions, it can also intensify intergroup conflict and amplify superstitious beliefs that impede the discovery and implementation of feasible strategies for solving real-world problems. What about the very real problem of seeking "world peace?"

The awarding of the 2014 Peace Prize maintained the Norwegian Nobel Committee's relatively new tradition of highlighting non-traditional avenues for peace making. ${ }^{1}$ During the last century the prize most often went to individuals who had contributed, in the words of Alfred Nobel's will, "to the abolition or reduction of standing armies and the formation and spreading of peace congresses." Recently, however, the award has sometimes gone to persons or groups who have promoted peace in other ways, such as raising awareness of climate change or fighting for human rights. In 2014 the Committee seemed to be sending the message: children are people too - and achieving and sustaining global peace will require renewed attention to the plight of young people, especially girls, in developing countries.

That year two well-known champions of children's rights, Kailash Satyarthi and Malala Yousafzai shared the Nobel Peace Prize "for their struggle against the suppression of children and young people and for the right of all children to education." Children, the Nobel Committee emphasized, "must go to school and not be financially exploited." In recent years, concern about these issues has increased in the international community, and a growing number of individuals and institutions have devoted themselves to remedying the situation. The good news is that today it is estimated that there are 78 million fewer child laborers in the world than there were in 2000 . The bad news is that the same calculations indicate that at least 128 million children continue to suffer under exploitative labor conditions. The 2013/14 United Nations Education for

1 This chapter is an adapted version of "Reflections on the 2014 Nobel Peace Prize," which was based on a lecture to the Agder Academy of Sciences and Letters, and originally published in Agder Vitenskapsakademi: Årbok 2014, ed. Jahr et al., (Kristiansand: Portal, 2015).

(C) F. LERON SHULTS, 2018 DOI 10.1163/9789004360952_012

This is an open access chapter distributed under the terms of the CC BY-NC-ND 4.o license. Shu lts - 9789004360952 
All: Global Monitoring Report estimated that 250 million children and young people are not learning basic skills as a result of inadequate access to educational resources.

In its official announcement of the 2014 award winners, the Nobel Committee went out of its way to emphasize that it "regards it as an important point for a Hindu and a Muslim, an Indian and a Pakistani, to join in a common struggle for education and against extremism." The tensions between India and Pakistan are complex and long-standing, and the Committee concluded that the efforts of Satyarthi and Yousafzai may very well aid in "the realization of the fraternity of nations," another of the criterion for the Peace Prize set out by Alfred Nobel in his will.

This chapter is divided into three parts. The first two sections briefly describe the backgrounds and provide summaries of the accomplishments of the 2014 Peace Prize winners. One of my main areas of expertise is the scientific study of religion, and so in the final section I offer some reflections on the ambiguous role of religion in the prizing of peace in an increasingly pluralistic, interconnected, and ecologically fragile global context.

\section{Kailash Satyarthi}

Born on 11 January 1954 in the Vidisha district of India, Kailash Satyarthi was educated as an electrical engineer. At age 26 he gave up his plans for an engineering career and began fighting for the liberation of Indian children who had been sold or forced into slave labor. In the words of the Nobel Committee: "Showing great personal courage, Kailash Satyarthi, maintaining Gandhi's tradition, has headed various forms of protests and demonstrations, all peaceful, focusing on the grave exploitation of children for financial gain." Some of Satyarthi's strategies have been quite daring and dangerous, including mounting raids on factories - often protected by armed guards - where children were being held captive and forced to work. In fact, it has been estimated that his grassroots efforts have led to the rescue of over 83,500 child slaves.

Satyarthi realized early on, however, that freeing children from such situations was only half the battle. It was also necessary to provide them with resources and opportunities for making a new life. As the Committee pointed out, he "has also contributed to the development of important international conventions on children's rights." Satyarthi has campaigned worldwide against child labor, arguing that it is intrinsically linked to other social problems such as the perpetuation of illiteracy, poverty, and population growth. 
He has worked with or served on the boards of numerous organizations committed to eradicating child labor and improving educational opportunities, including the Global March Against Child Labor, the South Asian Coalition on Child Servitude, and the International Center on Child Labor and Education.

In 1980, Satyarthi founded Bachpan Bachao Andolan (Save the Childhood Movement), which works with local villages and regional authorities to rehabilitate and educate children who are liberated from servitude. In 1994, he founded GoodWeave International (formerly known as Rugmark), a non-profit organization that monitors and audits companies that make hand-knotted carpets. Those companies that pass inspection are provided a GoodWeave logo that certifies that their product has been made without the use of child labor. Despite several attempts on his life over the decades, Satyarthi continues to work against child trafficking in India and worldwide, and for the rights of all children to attend school and to pursue a promising future.

\section{Malala Yousafzai}

Satyarthi's name may be new to some of you, but you would have to have been living in a cave the last three years not to have heard of Malala Yousafzai, the girl who - as the title of her autobiography puts it - "stood up for education and was shot by the Taliban." Born on 12 July 1997 in northwest Pakistan, Malala has often been in news headlines worldwide since October 2012, when a Taliban gunman attempted to assassinate her on a bus as she was returning home from an exam with her classmates. The bullet was not fatal, but she required multiple surgeries and was eventually treated in Great Britain, where she now attends school in Birmingham. Yousafzai was the first Pakistani and, at age 17, the youngest person ever to receive the Nobel Peace Prize.

In January 2009 she became а ввC blogger, anonymously providing a diary of her experiences in Swat Valley, and her reactions to the Taliban's destruction of schools and attempts to ban the education of girls. By late 2009 her identity had been revealed, and she became a public advocate for the rights of girls - and all children - to go to school. In the words of the Norwegian Nobel Committee: "Despite her youth, Malala Yousafzai has already fought for several years for the right of girls to education, and has shown by example that children and young people, too, can contribute to improving their own situations. This she has done under the most dangerous circumstances. Through her heroic struggle she has become a leading spokesperson for girls' rights to education." 
Prior to winning the Nobel Peace Prize, Yousafzai had also received several other awards - including Pakistan's National Youth Peace Prize (2011), the Sakharov Prize (2013), the Simon de Beauvoir Prize (2013) and the Ambassador of Conscience Award (2013). She has spoken around the world on themes related to children's rights to education. One of her most well known speeches was given at the United Nations on her 16th birthday, which was declared "Malala Day." During that speech she declared: "I do not even hate the Talib who shot me. Even if there is a gun in my hand and he stands in front of me. I would not shoot him. This is the compassion that I have learnt from Muhammad-the prophet of mercy, Jesus Christ, and Lord Buddha."

\section{Children, Religion, and Violence}

In its official announcement the Nobel Committee noted that "in the poor countries of the world, $60 \%$ of the present population is under 25 years of age," and insisted that "it is a prerequisite for peaceful global development that the rights of children and young people be respected. In conflict-ridden areas in particular, the violation of children leads to the continuation of violence from generation to generation." It is hard to argue with the logic of the Committee: a peaceful future depends on properly educating the next generation of human beings. It is also hard to imagine that anyone would challenge the passion that seems to have motivated the Committee's selection process this year: who could possibly be against helping children?

Who indeed? In fact, there are all too many industrialists and fundamentalists who seem to value their own acquisition of revenue or their own interpretation of religion above all else, leading to policies and practices that enslave or encumber children and women - and this is not limited to the developing world. My assignment for the lecture upon which this chapter was based was to introduce the 2014 winners and to offer some brief evaluative and contextualizing comments, not to analyze the deleterious effects of capitalist excess and religious fanaticism. However, I would like to complete my task by drawing attention to the ambiguity of the role of religion in the promotion of peace.

As I noted in my introductory comments, the Nobel Committee stressed the significance of the religious background of the Peace Prize winners - a Hindu and a Muslim - and praised their common struggle against extremism and for education. In fact, both Kailash Satyarthi and Malala Yousafzai often refer to their religious faith as grounding their compassionate and courageous efforts to facilitate peace in general and the welfare of children in particular. There is no doubt that there are powerful resources for motivating altruism in the 
Hindu and Islamic traditions. Like the other major religions that emerged in the wake of the axial age, their holy texts often encourage or even command justice and mercy.

However, it is also important to acknowledge that the global fight for the welfare of children, especially girls, will require fighting against the tide of traditional interpretations of such texts, which have in fact been used to sanction slavery and the oppression of women. The preference for boys over girls in the Brihadaranyaka Upanishad and Manusmriti, for example, is based on the assumption that only those reincarnated as males can perform the appropriate meritorious acts for liberating ancestors from sin. The fourth Surah of the Qur'an allows men to have sex with their slave girls and instructs husbands to beat their wives if they are unrepentantly disobedient or suspected of disloyalty. Similar examples of the privileging of men and the condoning of slavery and violence could be drawn from the Hebrew Bible and the New Testament.

Religion has in fact traditionally played a role in reinforcing sexism, as well as racism and classism - all biases that helped human groups hold together during the shift from small-scale hunter-gatherers to sedentary communities and the eventual emergence of regional empires. Today, however, most of us live in large-scale, pluralistic, globally interconnected societies. As we begin to feel the effects of our combined actions on an increasingly fragile ecological environment, we can no longer afford to appeal to supernatural agents in our attempts to make sense of nature and act sensibly in society. We must face these problematic aspects of the world's religious traditions head on. We certainly have a great deal to learn from Hinduism, Islam, and other axial religions as we try to cultivate peace both locally and across the globe.

But we have a harder row to hoe: unlearning the evolved tendency to imagine secretive and punitive gods who are invested in the behavior and survival of particular in-groups. If we hope to decrease the growing tensions between out-groups in a world with shrinking natural resources and an expanding population, we must develop the capacity to contest the evolved biases that engender religious superstition and segregation. Satyarthi and Yousafzai have significantly contributed to this process by questioning the attitudes and resisting the actions of those who try to manipulate the caste system in India and enforce universal Sharia law in Pakistan. In our rapidly globalizing context, the unveiling and unraveling of all forms of the religious oppression of women, children, and the poor have indeed become central tasks within the overall goal of promoting the prizing of peace.

Am I suggesting that these Nobel Prize winners should halt their efforts to make the world a more peaceful place? Obviously not. My point is that peace-making attempts that do not unveil the role that theist biases play in 
engendering and amplifying segregative behaviors and superstitious beliefs are leaving the job half-done. No, worse. They are inadvertently feeding the evolved biases that will continue to fuel the spiraling of intergroup conflict. There is no doubt that peace-making attempts that explicitly rely on and promote religious motivations can sometimes contribute to a temporary reduction of violence. However, statistical analyses of religion and conflict datasets indicate that competition among religious elites is often a precursor to conflicts, predicting their intensity and duration, and that the formation of interreligious dialogue networks are usually a reaction to earlier clashes between religions. ${ }^{2}$

In other words, such efforts may in fact be more a symptom of, rather than a cure for, religious conflict. Neither Satyarthi nor Yousafzai are religious elites and, like millions of other religious individuals, they exhibit laudable virtues that have been cultivated in the context of their participation in supernatural rituals and nurtured by their supernatural beliefs. But if this is the only way to cultivate such virtues, our species is in trouble. If we are serious about making peace in our current, globally interconnected environment, we will have to find the courage to speak clearly and straightforwardly about the consequences of religious sects.

2 See, e.g., Isaacs, "Faith in Contention: Explaining the Salience of Religion in Ethnic Conflict," Comparative Political Studies 32, no. 1 (2016); and Vüllers et al., "Measuring the Ambivalence of Religion: Introducing the Religion and Conflict in Developing Countries (RCDC) Dataset," International Interactions 41, no. 5 (2015). 